\title{
Good Corporate Governance Affects Company Value with Earnings Management as Intervening Variables in BUMN
}

\author{
Dwi Lia Feviana ${ }^{1 *}$, Supatmi ${ }^{2}$ \\ 1,2 Faculty of Economics and Business, Satya Wacana Christian University, Salatiga, Indonesia
}

\section{A R T I C L E I N F O}

Article history:

Received 27 January 2021

Received in revised form

5 February 2021

Accepted 18 February 2021

Available online 25

February 2021

Keywords:

Good Corporate Governance,

Earnings Management

\begin{abstract}
A B S T R A C T
Increasing company value is carried out by management (agents) who manage the company so that it triggers a conflict of interest so that Good Corporate Governance (GCG) is needed. One of the conflicts of interest is practicing earnings management. This study aims to analyze the effect of GCG on firm value mediated by earnings management. The sample used is 19 state-owned companies registered on the Indonesia Stock Exchange in 2017-2019. This study uses SEM-PLS analysis techniques to analyze data. The results showed that GCG had a negative effect on firm value and earnings management. Earnings management does not affect firm value. Earnings management, which is used as an intervening variable, cannot mediate the relationship between GCG and firm value. The limitations in this study are ignoring the variety of industries in BUMN, which may mean that each industry has different policies or practices on GCG and earnings management and different pressures from the market (investors).
\end{abstract}

Copyright (C) Universitas Pendidikan Ganesha. All rights reserved.

\section{Introduction}

Company value is one of the company's goals, which is reflected in the stock price. Public confidence in the performance and prospects of the company and good company value can be based on high share prices (Harmono, 2009). High share value can increase the welfare of shareholders (principal). The movement of company stock prices in Indonesia can be seen on idx.co.id, including the movement of the share price of state-owned companies (BUMN) that have gone public. Increasing company value is carried out by management (agents) who manage the company. However, in practice, management acts for personal gain through its authority (Tjandrakirana \& Monika, 2014). This creates a conflict of interest between shareholders and management. This conflict of interest is based on agency theory, one of the agency problems between the principal and the agent. Hence, a good corporate governance system is needed (Mahrani \& Soewarno, 2018).

Companies very much need good Corporate Governance (GCG) because GCG can help ensure that management acts in the company's best interests and that all stakeholders are treated equally to build shareholder trust. Good GCG can protect shareholders from getting a fair, precise, and efficient return on investment (Mahrani \& Soewarno, 2018). A survey said that investors are willing to pay more for companies that have good governance (McKinsey \& Company, 2001). Based on data from the Asian Development Bank Corporation, Indonesia ranks second lowest after Vietnam. Compared to other ASEAN countries, Indonesia's corporate governance score is lower (Asian Development Bank Corporation, 2017). Maintenance of good governance must be done to maximize company value and compete in the Global Market.

Research on the effect of GCG on firm value has been carried out extensively. Research conducted using a sample of manufacturing companies listed on the Jakarta Stock Exchange (JSE) in the 2002-2004 period (Murwaningsih, 2008). This study indicates that the number of boards of directors, managerial ownership, and institutional ownership has a significant positive effect on earnings management. The independent commissioner shows a significant negative effect, and the audit committee shows no significant effect. Some of the corporate governance variables show little influence on firm value, namely 
managerial ownership, institutional ownership, and board of directors. In contrast, other variables (board of commissioners and audit committee) significantly affect firm value.

Research on BUMN companies shows that corporate governance has a significant effect on firm value. The results showed that the concentration of ownership and managerial ownership had a negative effect on firm value. The number of board meetings had a positive effect on firm value. The board of commissioners and the number of board meetings did not affect firm value (Astrini, Biekayanti, and Suhardjanto, 2005). Other research shows that corporate social responsibility (CSR) results are rejected as an intervening variable in the corporate value GCG relationship (Purbopangestu \& Subowo, 2014). A research result conducted in listed firms in Nigeria stated that the board of commissioners and independent commissioners could reduce earnings management, while the role of CEO duality has a significant positive effect on earnings management (Uwuigbe, Peter, and Oyeniyi, 2014).

This study uses earnings management as a variable that can mediate the effect of GCG on firm value. The effect of GCG on firm value is direct and indirect through the company's earnings management practices. Acceptable GCG practices will reduce the company's earnings management practices and further encourage company value. However, if the company's GCG is good but its earnings management practices are high, the effect will not necessarily increase its value. Earnings management is proven to mediate the effect of GCG on company performance partially (Mahrani \& Soewarno, 2018). Earnings management can be slightly reduced by the presence of a GCG mechanism where adequate supervision by an independent commissioner and an external auditor's ability can minimize the possibility of corporate fraud and ultimately increase firm value.

This study's object used state-owned companies listed on the Indonesia Stock Exchange (BEI) in 2017-2019. State-owned companies are corporations whose majority ownership is owned by the government. Many investors invest in BUMN companies because they are not sure about private companies. BUMN companies are considered not to commit fraud against investors, and BUMN companies have high dividend pay-out (Salim, 2010). Several state-owned companies also often fall into the category of blue-chip stocks or stocks with a good reputation so that they are in great demand by investors (Darmadji \& Fakhruddin, 2011). On the other hand, this study found several cases of state-owned companies that carried out earnings management, namely Garuda Indonesia and Jiwasraya. Garuda Indonesia in 2018 reported financial statements with a profit of US $\$ 809.85$ thousand, and the financial statements did not receive approval from two of its commissioners because they were deemed not following the statement of financial accounting standards (PSAK) number 23 concerning income (Afriyadi, 2019). Another case is Jiwasraya, BPK revealed that there was a manipulation of profits of Rp. 360.3 billion in 2006 (Putri, 2020). This shows that SOEs are also vulnerable to earnings management practices.

This study aims to find empirical evidence of the impact of GCG on firm value by predicting earnings management as an intervening variable in this causal relationship. This study's results are expected to contribute to adding empirical results related to agency theory in the SOE sector in emerging market countries (Indonesia). For the company, this study's results are expected to be an aspect of consideration in GCG practice. For investors, this study's results are expected to be an aspect of consideration for making investment decisions. For 0JK, these research results are expected to be an aspect of consideration in making policies that regulate governance provisions (GCG) in BUMN.

\section{Methods}

The research method used is a type of quantitative approach. This research was conducted to determine the causal relationship between variables. This study's population are state-owned companies listed on the Indonesia Stock Exchange (BEI) for the 2017-2019 period. The sampling technique in this study used Judgment Sampling. The population selected becomes the sample based on the judgment or judgment of the researcher. The company chosen is a company that publishes annual reports consistently in 2017-2019, has information on stock market prices available on the Indonesia Stock Exchange Web (www.idx.co.id) in 2017-2019, and has information on GCG practice variables in the annual reports published in 2017-2019. Based on these criteria, 19 samples of BUMN companies were obtained with a total of 57 observations, as shown in Table 1.

Table 1. Population and Sample

\begin{tabular}{llc}
\hline No & \multicolumn{1}{c}{ Criteria } & Number of Companies \\
\hline 1 & Issuers that are members of the Indonesia Stock Exchange (IDX) in & 20 \\
2 & the 2017-2019 period & Did not publish annual reports for 2017 to 2019 \\
\hline
\end{tabular}




\begin{tabular}{lcc}
\hline No & Criteria & Number of Companies \\
\hline Final sample number $(\mathrm{i})$ & & 19 \\
Number of years $(\mathrm{t})$ & 3 \\
Number of observations $\left(\mathrm{i}^{*} \mathrm{t}\right)$ & & 57 \\
\hline
\end{tabular}

This study uses secondary data in the form of annual reports of state-owned companies listed on the IDX. The data collection technique uses documentation studies, which are carried out by collecting, reading, and identifying published annual reports of BUMN companies. The company's annual report can be obtained through the Indonesia Stock Exchange Web (www.idx.co.id).

This research uses the firm value as the dependent variable, which is proxied by Tobins' Q (TQ). Tobin's $Q$ explains that firm value is a combination of tangible assets and intangible assets (Lindenberg \& Ross, 1981). Corporate Governance is an independent variable in this study which is measured using 5 indicators, namely: Managerial Ownership, Institutional Ownership, Independent Board of Commissioners, Audit Committee, Audit Quality (Mahrani \& Soewarno, 2018; Murwaningsih, 2008). The description of each indicators is shown in Table 2.

Table 2. Indicators of Corporate Governance

\begin{tabular}{ll}
\hline \multicolumn{1}{c}{ Indicator } & \multicolumn{1}{c}{ Description } \\
\hline $\begin{array}{l}\text { Managerial Ownership } \\
\text { (MO) }\end{array}$ & $\begin{array}{l}\text { Managerial ownership (MO) is the percentage of share ownership } \\
\text { owned by management who is actively involved in making decisions }\end{array}$ \\
$\begin{array}{l}\text { Institutional Ownership } \\
\text { (IO) }\end{array}$ & $\begin{array}{l}\text { Institutional ownership (IO) is the percentage of company share } \\
\text { ownership by other institutions (Perwitasari, 2014). }\end{array}$ \\
$\begin{array}{l}\text { Independent Board of } \\
\text { Commissioners (IBC) }\end{array}$ & $\begin{array}{l}\text { The independent board of commissioners (IBC) is measured by looking } \\
\text { at the proportion between the number of commissioners from outside } \\
\text { the company with the total commissioners of the company. }\end{array}$ \\
Audit Committee (AC) & $\begin{array}{l}\text { BAPEPAM-LK No: Kep-643/BL/2012 stated that the minimum audit } \\
\text { committee consists of 3 persons from independent commissioners or } \\
\text { parties from outside the company. } \\
\text { Audit quality is proxied by looking at the public accounting firm that } \\
\text { audits the company. This variable is measured by a dummy, 1 given } \\
\text { when the company's financial statements are audited by big four } \\
\text { accounting firms and 0 otherwise. Big four accounting firms consist of: } \\
\text { Deloitte, Ernst \& Young (EY), KPMG, and PricewaterhouseCoopers } \\
\text { (PwC). }\end{array}$ \\
\hline
\end{tabular}

Earnings management is an intervening variable measured by the modified Jones model to find the discretionary accrual (DTAC) value which is a proxy for earnings management. The modified Jones model is considered the best model compared to other models in measuring earnings management (Dechow, Sloan, \& Sweeney, 2015).

This study uses company size as a control variable. The size of the company is a political cost hypothesis, which means that there are political actions in large companies that cause costs, this condition will encourage management to choose accounting methods that reduce or avoid costs arising from these political actions. (Watts \& Zimmerman, 1986). The firm size variable will be measured by the natural logarithm of total assets (Chtourou, Bedard, \& Courteau, 2001). The analysis model to measure the direct and indirect effects in research uses the partial least square (PLS) model. Testing with this model uses the Smart-PLS version 03 software as an analysis tool.

\section{Results and Discussions}

\section{Descriptive Statistics}

Descriptive statistical data is used to identify the minimum value, maximum value, average value, and standard deviation of each variable indicator. The results of the variable data description of this study are shown in Table 3. 
Table 3. Results of Descriptive Statistical Analysis

\begin{tabular}{lccccc}
\hline $\begin{array}{l}\text { Research } \\
\text { variable }\end{array}$ & N & Mean & Min & Max & Standard Deviation \\
\hline Tobins'Q & 57 & 1,839 & 0,735 & 14,623 & 2,474 \\
MO & 57 & 0,000 & 0,000 & 0,004 & 0,001 \\
IO & 57 & 0,294 & 0,063 & 0,490 & 0,119 \\
IBC & 57 & 0,401 & 0,200 & 0,625 & 0,109 \\
AC & 57 & 1,403 & 0,667 & 2,333 & 0,408 \\
AQ & 57 & 0,667 & 0,000 & 1,000 & 0,471 \\
Size & 57 & 30,790 & 22,049 & 34,887 & 3,336 \\
DAC & 57 & 0,003 & $-0,131$ & 0,153 & 0,055 \\
\hline
\end{tabular}

The Tobins'Q variable, a proxy for company value, has an average value of 1.839 . This shows that the company's value under study is relatively high, as reflected by the average value greater than 1 . This indicates that the market value is higher than the asset value, so it can be concluded that the market gives more valuation to the company.

The corporate governance (GCG) aspect seen from the Managerial Ownership (MO) variable in Table 3 shows that in general BUMN companies, the minimum managerial ownership is indicated by an average value close to the value of 0 alias almost non-existent. This shows that managerial ownership in the company studied is very low. This indicates that the management's share ownership program in the company is very low or non-existent. The Institutional Ownership (IO) variable has an average of 0.294. This shows that another institutional ownership in BUMN companies is low. The ownership of institutions is scattered by the Government of Indonesia so that other institutions only have a percentage of about $30 \%$ of the remaining is owned by local or foreign individuals.

In Table 3, the Independent Board of Commissioner (IBC) variable has an average value of 0 . This result shows that most of the board of commissioners are not affiliated or independent. This means that the number of commissioners in a company, most of whose members are half, are independent commissioners. The Audit Committee variable (AC) has an average of 1.403 . So it can be concluded that most state-owned companies have strictly complied with the company audit committee's criteria issued by BAPEPAM-LK No: Kep-643 / BL / 201. The audit committee in a publicly listed company has at least 3 (three) members of the audit committee. The Audit Quality Variable (AQ) has an average of 0.667. This shows that most of the BUMN company reports were audited by the big four KAP.

The aspect of company earnings management as seen from the DAC variable in table 2 shows an average value of 0.003 . This shows that earnings management tends not to be carried out in state-owned companies as reflected in the average value, which does not reach 1 . This means that earnings management practices during the study period were detected to be very low. The variable Size or company size has an average value of 30,790 with a maximum value of 34,887 and a minimum value of 22,049 .

Table 4. Correlation Test Results

\begin{tabular}{lcccccccc}
\hline & MO & IO & IBC & AC & AQ & Size & DAC & Tobins'Q \\
\hline MO & 1.00 & & & & & & & \\
IO & 0.03 & 1.00 & & & & & & \\
IBC & -0.09 & 0.25 & 1.00 & & & & & \\
AC & 0.02 & 0.43 & 0.56 & 1.00 & & & & \\
AQ & 0.11 & 0.44 & 0.16 & 0.49 & 1.00 & & & \\
Size & 0.10 & 0.47 & 0.32 & 0.40 & 0.18 & 1.00 & & \\
DAC & 0.28 & -0.24 & -0.23 & -0.19 & -0.14 & -0.04 & 1.00 & \\
Tobins'Q & -0.08 & -0.21 & -0.20 & -0.31 & -0.34 & -0.16 & -0.11 & 1.00 \\
\hline
\end{tabular}

Based on the results of Table 4, it can be interpreted that the correlation between the indicators of the variables MO, IO, IBC, AC, AQ, Size, and DAC has a very low correlation with Tobins'Q. The indicators for IO, IBC, AC, and AQ have a very low correlation with DAC, while MO shows a low correlation.

\section{PLS Model Testing}

The first stage of the PLS model test is the outlier test, which includes the construct reliability and validity test, the multicollinearity test, and the R square test. Reliability testing is done by looking at the 
Cronbach's Alpha value. This value can reflect the reliability value of all indicators in the research model. The minimum value in reliability testing is 0.7 , while the ideal is 0.8 or 0.9 . Validity testing can be seen from the Average Variance Extracted (AVE) value; at least the AVE value is 0.5.

Table 5. Construct Reliability and Validity Test

\begin{tabular}{llll}
\hline & $\begin{array}{l}\text { Cronbach's } \\
\text { Alpha }\end{array}$ & $\begin{array}{l}\text { Average } \\
\text { (AVE) }\end{array}$ & Variance \\
\hline GCGtracted & 0,63 \\
Earning management & 0,71 & 1,00 & \\
Company Value & 1,00 & 1,00 & \\
Company Size & 1,00 & 1,00 & \\
\hline
\end{tabular}

Based on Table 5, reliability and validity testing, the GCG variable has a Cronbach's alpha value of 0.71 and AVE of 0.63. Earnings management variables, firm value, and firm size in reliability and validity testing show a value of 1 . This means that all variables have sufficient reliability and validity values.

Table 6. Multicollinearity Test

\begin{tabular}{ll}
\hline & VIF \\
\hline KA & 1,413 \\
KI & 1,340 \\
QA & 1,436 \\
Size & 1,000 \\
DAC & 1,000 \\
Tobins' Q & 1,000 \\
\hline
\end{tabular}

The results of the multicollinearity test carried out on the data used show that the VIF value does not exceed the standard tolerance of 10 . This proves the absence of colinearity in the independent variables used.

Table 7. R Square test

\begin{tabular}{ll}
\hline Dependent & R Square \\
\hline Earnings management & 0.060 \\
Tobins' Q & 0.175 \\
\hline
\end{tabular}

The results of the $\mathrm{R}$ Square test illustrate the magnitude of the influence of the independent variable on the dependent variable. Table 7 shows the results of R Square on earnings management of 0.060 or $6 \%$. This explains that GCG and company size affect earnings management by $6 \%$, besides that it is influenced by other factors outside the model. The value of R Square on firm value is 0.175 or $17.5 \%$, which means that the effect of GCG and earnings management on firm value is only $17.5 \%$ while the rest is influenced by other factors outside the model.

\section{Hypothesis Test}

Hypothesis testing is done to prove the truth of the hypothesis built, namely the direct effect between variables using SmartPLS. The test results can be seen in Table 8.

Table 8. Hypothesis Test Results

\begin{tabular}{lclll}
\hline & $\begin{array}{l}\text { Original } \\
\text { Sampel }\end{array}$ & $\begin{array}{l}\text { T- } \\
\text { Statistic }\end{array}$ & $\begin{array}{l}\text { P- } \\
\text { Value }\end{array}$ & Conclusion \\
\hline GCG $\rightarrow$ The value of the company & $-0,414$ & 3,271 & 0,001 & H1 ditolak \\
GCG $\rightarrow$ Earnings management & $-0,269$ & 2,026 & 0,022 & $\begin{array}{l}\text { H2 } \\
\text { diterima }\end{array}$ \\
$\begin{array}{l}\text { Earnings management } \rightarrow \text { The value of the } \\
\text { company }\end{array}$ & $-0,212$ & 1,217 & 0,112 & H3 ditolak
\end{tabular}




\begin{tabular}{lcccc}
\hline & $\begin{array}{l}\text { Original } \\
\text { Sampel }\end{array}$ & $\begin{array}{l}\text { T- } \\
\text { Statistic }\end{array}$ & $\begin{array}{l}\text { P- } \\
\text { Value }\end{array}$ & Conclusion \\
\hline $\begin{array}{l}\text { GCG } \rightarrow \text { Earnings management } \rightarrow \text { The value of } \\
\text { the company }\end{array}$ & 0.057 & 1.103 & 0.135 & H4 ditolak \\
\hline
\end{tabular}

The effect of GCG on firm value shows a negative direction with a p-value of less than $5 \%$. This shows that GCG has a negative effect on firm value, which is not in line with the hypothesis that GCG has a positive effect on firm value. Thus hypothesis 1 is not supported.

GCG negatively affects earnings management with a p-value of less than $5 \%$. This means that GCG has a negative effect on company value, and this is in line with the hypothesis that GCG has a negative effect on company management. Thus hypothesis 2 is not supported.

Earnings management has a negative influence on firm value with a p-value of more than $5 \%$. This means that earnings management has a negative effect on firm value, which means that it is not in line with the hypothesis built to consider hypothesis 3 .

The effect of GCG on firm value mediated by earnings management shows a p-value of more than $5 \%$ in a positive direction. This shows that GCG does not affect firm value mediated by earnings management. This is not in line with the hypothesis that GCG affects firm value mediated by earnings management. Thus hypothesis 1 is rejected.

\section{Discussion \\ Good Corporate Governance and Company Value}

This study found that good corporate governance has a negative effect on firm value. This means that the better corporate governance, the lower the company's value in investors' eyes. BUMN companies are required to practice GCG, as stipulated in the Regulation of the State Minister for State-Owned Enterprises Number: PER-01 / MBU / 2011 concerning the Implementation of Good Corporate Governance State-Owned Enterprises. BUMN companies may have implemented GCG practices, but the implementation has not been maximally applied to the company, while the costs incurred for implementing GCG are not small. GCG practices carried out by companies may only be for formality as the fulfilment of company obligations in government regulations so that their implementation is not optimal. Good GCG is in line with the costs of carrying out GCG activities. According to investors, this is considered inefficient or wasteful and results in a decrease in company value.

The results of this study are not in line with Fallatah and Dickins (2012); Suhadak et al. (2019); and Purbopangestu and Subowo (2014), which states that GCG has a positive effect on company value. This study's results are in line with the research of Mutmainah (2015), which states that GCG has a negative effect on company value.

\section{Good Corporate Governance and Earnings Management}

Good corporate governance in this study was found to have a negative effect on earnings management. This shows that improving GCG will provide more supervision to management to manage the company well. This supervision can prevent or reduce earnings management actions because such supervision is an incentive for management as an agent to act in the best possible interest of the principal and suppress deviant behaviour. In addition to monitoring, GCG practices also uphold the principle of independence to raise concerns that if earnings management is detected and revealed, it will destroy its reputation. This can minimize the case for earnings management and increase the credibility of accounting information in financial reports.

The results of this study are in line with Mahrani and Soewarno (2018); Uwuigbe et al. (2014); Kamran and Shah (2014); and Lee et al. (2012), which states that GCG has a negative and significant effect on earnings management. This study's results are inconsistent with the research of Hermiyetti and Manik (2013), which states that GCG does not have a significant effect on earnings management.

\section{Earnings Management and Company Value}

Earnings management was found not to influence firm value. Earnings management practices carried out by managers will not have a reaction that impacts firm value. Earnings management in BUMN companies is deficient so that it does not influence company value (Chandra \& Deviesa, 2017). This may be because the influence of the most extensive ownership of BUMN companies is the government. The practice of earnings management can be avoided because it will damage the government's reputation if it is done and detected.

Another thing that may affect the failure to carry out earnings management is the market reaction that does not last long and, if detected, will impact the reputation and value of the company. Earnings 
performance resulting from the accrual component as an earnings management activity has less persistent earnings than cash flow (Sloan, 1996). This can increase the value of the company at certain times, but it will not last long.

The results of this study are not in line with Fernandes and Ferreira (2007); Tangjitprom (2013); and Gill et al. (2013), which states that earnings management has a negative effect on firm value. This study's results are in line with the research conducted by Lestari and Ningrum (2018) which states that earnings management does not affect firm value.

\section{Good Corporate Governance, Earnings Management and Company Value}

Good corporate governance does not affect firm value mediated by earnings management. GCG practices carried out in audit committee supervision, good audit quality, and the amount of institutional ownership owned by the government are proven to suppress earnings management practices. BUMN companies are under government control if BUMN companies carry out earnings management and are detected to destroy the government's reputation and public trust. Large government ownership makes earnings management practices very low to do. This makes earnings management unable to affect firm value because earnings management practices are detected very low. The absence of a direct effect of earnings management on firm value can be a factor causing the inability of management to mediate the effect of GCG on firm value.

Research results are inconsistent with Mahrani and Soewarno (2018), which states that GCG has a negative and significant influence on the GCG mechanism mediated by earnings management. This study's results are in line with Murwaningsih (2008), which states that earnings management is not proven to be an intervening variable between GCG and firm value.

\section{Conclusion}

The results of testing and analysis indicate that GCG has a negative effect on firm value and earnings management. This study indicates that the better the GCG, the lower the firm value and earnings management practices. Meanwhile, the test and analysis results show that earnings management has no influence on firm value and does not mediate the effect of GCG on firm value. GCG cannot affect earnings management so that it cannot react to firm value. This study's results strengthen empirical evidence related to agency theory in the BUMN sector in the context of the effect of GCG on earnings management. These findings confirm agency theory that GCG can suppress agency problems, namely earnings management, to increase investor and public confidence, especially in state-owned companies. This research can also provide advice to companies to remain consistent and improve GCG practices. Investors may consider investing in state-owned companies because their earnings management tends to below. Meanwhile, for regulators, this research can consider making policies regarding corporate governance mechanisms, especially in the BUMN sector. The limitations in this study are ignoring the variety of industries in BUMN, which may mean that each industry has different policies or practices on GCG and earnings management and different pressures from the market (investors). Suggestions for further research, use different samples so that observations become variance. Using other independent variables that are thought to affect firm value, if you keep using the same variables, use different indicators that are thought to be able to explain related variables such as the number of attendance at board meetings.

\section{References}

Afriyadi, A. D. (2019). Kisruh Laporan Keuangan Garuda: Ditolak Komisaris hingga Terbukti Cacat. https://finance.detik.com/bursa-dan-valas/d-4603814/kisruh-laporan-keuangan-garudaditolak-komisaris-hingga-terbukti-cacat.

Asian Development Bank Corporation. (2017). ASEAN Corporate Governance Scorecard Country Reports and Assessments 2015. Asian Development Bank.

Astrini, S. F., Biekayanti, G., \& Suhardjanto, D. (2005). Praktik corporate governance dan nilai perusahaan BUMN di Indonesia. Jurnal Akuntansi, XIX(01), 1-30. http://dx.doi.org/10.24912/ja.v19i1.111.

Chtourou, S. M., Bedard, J., \& Courteau, L. (2001). Corporate governance and earnings management. SSRN Electronic Journal. https://doi.org/10.2139/ssrn.275053.

Darmadji, T., \& Fakhruddin, H. M. (2011). Pasar modal di Indonesia. Salemba Empat.

Dechow, P. M., Sloan, R. G., \& Sweeney, A. P. (2015). Detecting earnings management. Asian Financial 
Statement Analysis, 70(2), 73-105. https://doi.org/10.1002/9781119204763.ch4.

Fallatah, Y., \& Dickins, D. (2012). Corporate governance and firm performance and value in Saudi Arabia. African Journal of Business Management, 6(36), 10025-10034. https://doi.org/10.5897/AJBM12.008.

Fernandes, N. G., \& Ferreira, M. A. (2007). The Evolution of Earnings Management and Firm Valuation: A Cross-Country Analysis. In EFA 2007 Ljubljana Meetings Paper. https://doi.org/10.2139/ssrn.965636.

Gill, A., Biger, N., Mand, H. S., \& Mathur, N. (2013). Earnings management, firm performance, and the value of indian manufacturing firms. International Research Journal of Finance and Economics, 116. https://scholarworks.waldenu.edu/sm_pubs/65/.

Harmono. (2009). Manajemen keuangan: Berbasis balanced scorecard pendekatan teori, kasus dan riset bisnis. Bumi Aksara.

Hermiyetti, \& Manik, E. N. (2013). The influence of good corporate governance mechanism on earnings management : Empirical study in indonesian stock exchange listed company for periods of 20062010. Indonesian Capital Market Review, 5(1). https://doi.org/10.21002/icmr.v5i1.1583.

Kamran, \& Shah, A. (2014). The impact of corporate governance and ownership structure on earnings management practices: evidence from listed companies in Pakistan. The Lahore Journal of Economics, 2, 27-70. https://doi.org/10.35536/lje.2014.v19.i2.a2.

Lee, T., Road, D.-H., Ku, C., Chen, H., \& Chen, J. (2012). A study of corporate governance factors and earnings management behaviors of Taiwan public companies. International Journal of Business, $\begin{array}{llll}\text { Humanities } & \text { and }\end{array}$ http://ijbhtnet.com/journals/Vol_2_No_5_August_2012/8.pdf.

Lestari, N., \& Ningrum, S. A. (2018). Pengaruh manajemen laba terhadap nilai perusahaan dengan tax avoidance sebagai variabel vediating. Journal of Applied Accounting and Taxation, 1(3), 99-109. https://doi.org/10.30596/liabilities.v1i3.2496.

Lindenberg, E. B., \& Ross, S. A. (1981). Tobin's q ratio and industrial organization. The Journal of Business, 54(1), 1. https://doi.org/10.1086/296120.

Mahrani, M., \& Soewarno, N. (2018). The effect of good corporate governance mechanism and corporate social responsibility on financial performance with earnings management as mediating variable. Asian Journal of Accounting Research, 3(1), 41-60. https://doi.org/10.1108/AJAR-06-2018-0008.

McKinsey \& Company. (2001). Investor opinion survey on corporate governance. McKinsey and Company.

Murwaningsih, E. (2008). Pengaruh corporate governance terhadap nilai perusahaan dengan manajemen laba sebagai variabel intervening (Studi pada perusahaan manufaktur di BEJ). Jurnal Ekonomi: Media Ilmiah Indonesia, 364-383. http://riset.unisma.ac.id/index.php/jrm/article/view/4449.

Mutmainah. (2015). Analisis good corporate governance terhadap nilai perusahaan. Eksis: Jurnal Riset Ekonomi Dan Bisnis, Vol. X(No.2, Oktober), pp: 1-15. https://doi.org/https://doi.org/10.26533/eksis.v10i2.63.

Perwitasari, D. (2014). Struktur kepemilikan, karakteristik perusahaan, dan manajemen laba. Jurnal Akuntansi Multiparadigma, 5(3). https://doi.org/10.18202/jamal.2014.12.5032.

Purbopangestu, H. W., \& Subowo. (2014). Pengaruh good corporate governance terhadap nilai perusahaan dengan corporate social responsibility sebagai variabel intervening. Accounting Analysis Journal, 3(3). https://doi.org/10.15294/aaj.v3i3.4202.

Putri, C. A. (2020). Kacau! BPK Sebut Jiwasraya Manipulasi Laba. https://www.cnbcindonesia.com/market/20200108162637-17-128611/kacau-bpk-sebutjiwasraya-manipulasi-laba.

Salim, J. (2010). 108 Tanya Jawab Tentang Investasi. Visimedia.

Sloan, R. G. (1996). Do stock prices fully reflect information in accruals and cash flows about future earnings? Accounting Review, 71(3), 289-315. https://www.jstor.org/stable/248290. 
Suhadak, S., Kurniaty, K., Handayani, S. R., \& Rahayu, S. M. (2019). Stock return and financial performance as moderation variable in influence of good corporate governance towards corporate value. Asian Journal of Accounting Research, 4(1), 18-34. https://doi.org/10.1108/ajar-07-2018-0021.

Tangjitprom, N. (2013). The role of corporate governance in reducing the negative effect of earnings management. International Journal of Economics and Finance, 5(3), 213-220. https://doi.org/10.5539/ijef.v5n3p213.

Tjandrakirana DP, R., \& Monika, M. (2014). Pengaruh kinerja keuangan terhadap nilai perusahaan pada perusahaan manufaktur yang terdaftar di Bursa Efek Indonesia. Jurnal Manajemen Dan Bisnis Sriwijaya, 12(1), 1-16. https://doi.org/10.29259/jmbs.v12i1.3136.

Uwuigbe, U., Peter, D. S., \& Oyeniyi, A. (2014). The effects of corporate governance mechanisms on earnings management of listed firms in Nigeria. Journal of Accounting and Management Information Systems, 13(1), 159-174. http://eprints.covenantuniversity.edu.ng/8127/.

Watts, R. L., \& Zimmerman, J. L. (1986). Positive accounting theory. Englewood Cliffs, N.J: Prentice-Hall. 